\title{
Zmienność postrzegania bryły dachu w zależności od odziaływania różnych czynników zewnętrznych
}

\section{Variability of perception of the body of the roof, depending on the effect of different external} factors

\begin{abstract}
Streszczenie
Postrzeganie bryły dachu, jak i każdego innego dzieła architektonicznego oraz całej otaczającej nas przestrzeni ma charakter bardzo złożony i jest uzależnione od wielu czynników. Należą do nich zarówno właściwości percepcyjne, motoryczne, fizyczne i psychiczne człowieka jako jednostki, jak i zewnętrzne cechy, leżące po stronie przedmiotu obserwowanego. W artykule postarano się przybliżyć tę problematykę.
\end{abstract}

Słowa kluczowe: postrzeganie, percepcja wzrokowa, architektura, geometria bryły dachu

\section{Abstract}

Perception of the body of the roof, as well as of any other work of architecture and the entire space that surrounds us, is extremely complex and it depends on numerous factors. These include perceptive, motor, physical, and mental properties of a human being as an individual, as well as external features, pertaining to the observed object. This paper offers an insight into this subject.

Keywords: perception, visual perception, architecture, geometry of the body of the roof 
Postrzeganie bryły dachu, jak i każdego innego dzieła architektonicznego oraz całej otaczającej nas przestrzeni ma charakter bardzo złożony i jest uzależnione od wielu czynników. Czynniki te można pogrupować w trzy główne „wymiary”, które mają wpływ na postrzeganie przestrzeni przez człowieka.

Podział ten można przedstawić następująco:

1. WYMIAR

MOŻLIWOŚCI WZROKU, SŁUCHU, WĘCHU I DOTYKU

- ostrość wzroku, słuchu, powonienia, wrażliwość dotyku,

- pole widzenia, zakres słyszalności, odbierania zapachów, rozróżniania powierzchni,

- motoryka ${ }^{1}$,

- funkcje mózgowe,

- recepcja² światła, barw, dźwięków, zapachów, struktur.

2. WYMIAR

WYPOSAŻENIE I PREDYSPOZYCJE INDYWIDUALNE

- cechy fizyczne,

- cechy psychiczne,

- percepcja ${ }^{3}$,

- integracja sensoryczna ${ }^{4}$,

- poznanie.

3. WYMIAR

CZYNNIKI ZEWNĘTRZNE

- barwa, ton, zapach, faktura,

- kontrast,

- czas działania danego bodźca, który jest potrzebny do postrzeżenia go, lub czas, przez jaki on działa,

- przestrzeń,

- oświetlenie, akustyka, cyrkulacja, wilgotność powietrza, temperatura.

Zmiany w jednym z wymienionych powyżej składników mogą znacząco wpłynąć na zmiany innych składników lub nawet całych wymiarów. Przykładowo zmiana rozmiaru obiektu lub też jego oświetlenia może zmniejszyć (lub zwiększyć) czas potrzebny do jego „prezentacji”.

Dwa pierwsze wymiary zawierają uwarunkowania do postrzegania ${ }^{5}$ dowolnego obiektu w sposób indywidualny, ponieważ znajdują się w każdym z nas.

Są to uwarunkowania typu:

\section{FIZJOLOGICZNEGO I PSYCHOLOGICZNEGO}

Pierwsze z nich, czyli uwarunkowania typu fizjologicznego, to te informacje, które rejestrują nasze narządy wzroku, słuchu, powonienia czy też dotyku. Ale obraz rzeczywistości 
powstały (zarejestrowany) za ich pośrednictwem jest jedynie zespołem nic nie znaczących sygnałów (znaków), jakie zostały zarejestrowane i przekazane do kory mózgowej.

Gdyby postawić np. pytanie:

\section{W jaki sposób widzimy?}

To odpowiedz byłaby prosta:

Widzimy mózgiem, a nie oczami.

Ponieważ to, co nazywamy widzeniem, jest w rzeczywistości wynikiem niezwykłej wędrówki światła przez system wzrokowy mózgu.

Przetwarzanie światła rozpoczyna się w oczach, które są połączone z mózgiem. Są one również najbardziej zewnętrznym fragmentem centralnego układu nerwowego. Światło zostaje złapane i zogniskowane w siatkówce oka, następnie przetworzone na impulsy elektryczne i przesłane nerwami wzrokowymi do mózgu. Tam impulsy biegną do ośrodka wzroku, mieszczącego się w tylnej części mózgu, gdzie przekształcane są na wrażenia wzrokowe. Dzięki temu, że faktycznie widzimy mózgiem, uszkodzenie pewnych obszarów mózgu może spowodować całkowitą ślepotę nawet u osób, których oczy są zdrowe. Można powiedzieć, że takie osoby patrzą, lecz nie widzą .

Podobnie przedstawia się sytuacja z pozostałymi zmysłami. Sygnał, jaki został przekazany do kory mózgowej, umożliwia nam jedynie widzenie obrazu, czucie zapachu itp. - nie umożliwia nam natomiast rozpoznawania, co on przedstawia, zapamiętywania go czy też przypominania sobie obrazów wcześniej widzianych. Dzięki niemu możemy jedynie np. odebrać percepcję kształtu oraz barwy oglądanego obiektu architektonicznego. A przecież na tym widzenie nie polega, ponieważ nie jest ono jedynie postrzeganiem ludzi i przedmiotów, lecz rozpoznawaniem, kim lub czym są w rzeczywistości.

Ponadto badania mechanizmu wzroku wykazały, że obrazy, które docierają do siatkówki, są dwuwymiarowe, płaskie jak fotografia - mimo iż w rzeczywistości świat jest trójwymiarowy i takim go widzimy. Obraz odbierany przez oczy jest też ustawiony do góry nogami, a jednak mózg ustawia go we właściwej pozycji.

Świadome widzenie świata jest połączone ze zdolnością przypominania i zapamiętywania widzianych obiektów, czyli np. rzeczywisty proces widzenia jest zależny od czynności innych części mózgu niż te, do których dochodzi sygnał z siatkówki oka.

Dopiero uwarunkowania typu psychicznego pozwalają nam zrozumieć znaczenie tych sygnałów ${ }^{7}$. Obrazy, które odbieramy wzrokiem i które zostają przekazane do mózgu, poddawane są przez niego koniecznym poprawkom, ponieważ oczekuje on, by miały one cechy charakterystyczne dla świata zewnętrznego - takie jak np. trójwymiarowość. Mózg również świetnie wie, gdzie jest góra, a gdzie dół. Od momentu narodzin mózg jest wyczulony na bodźce wzrokowe, które odpowiadają jego wrodzonemu sposobowi rozumienia 
rzeczywistości, a w procesie postrzegania czynnik psychologiczny sprawia, że człowiek osiąga umiejętność nadawania tym sygnałom ${ }^{8}$ odpowiednich treści.

W tych psychicznych procesach zachodzących w mózgu doświadczenie zdobyte w przeszłości ma niemal taką sama ważność dla odbierania przestrzeni oraz zrozumienia tego, co się dzieje wokoło, jak właśnie pobudzone różne receptory i sygnały, jakie zostały przez nie pozyskane do odpowiedniego obszaru kory mózgowej. Nasz mózg przechowuje obrazy widzianych miejsc, osób czy zdarzeń, a w miarę potrzeby uzupełnia brakujące fragmenty widzianych obrazów, pozwalając odczytać ich sens.

Zresztą samo widzenie obiektu to jeszcze nie wszystko. Ważne jest, by wiedzieć, gdzie się on znajduje względem nas samych. Nasz mózg jest w stanie to określić dzięki umiejętności zwanej widzeniem głębi przestrzeni.

Jednym z najważniejszych zjawisk związanych z odbieraniem głębi przestrzeni jest widzenie dwuoczne, czyli binokularne.

Obrazy, jakie powstają na siatkówkach obu naszych oczu, różnią się nieco od siebie. Jest to podyktowane tym, że oczy są od siebie nieco oddalone, a co zatem idzie, promienie z każdego punktu przedmiotu docierają do lewego i prawego oka pod innym kątem. Złożenie tych obrazów w mózgu daje stereoskopowość, czyli wrażenie głębi.

Samo wrażenie głębi powstaje z udziałem wielu czynników, ale główną rolę odgrywają czynniki psychologiczne. Obrazy, jakie powstają na siatkówkach oczu, są tylko bazą fizjologiczną, a całe przekształcenie i „zobaczenie obiektu” powstaje w mózgu w wyniku porównywania różnic, jakie mają przesłane do mózgu obrazy z obu siatkówek.

W tym miejscu warto zacytować Ogle, który na temat stereoskopii napisał:

Stereoskopia jest zjawiskiem zmysłowym, rządzącym się własnymi prawami i mającym własny mechanizm fizjologiczny. Dany osobnik albo ją posiada, albo nie. Ćwiczenie wydaje się bez wpływu na rozwój stereoskopii jako takiej, może ono jednak powiększyć zdolność danej osoby do rozróżniania różnic w głębokości, podobnie jak w przypadku ostrości wzroku, którą można nieco poprawić przez ćwiczenie. Ale należy pamiętać, że widzenie dwuoczne jest tylko jedną z metod, jakimi mózg posługuje się przy odbieraniu głębi przestrzeni. Dlatego wiele osób niewidomych na jedno oko widzi głębię przestrzeni ${ }^{10}$.

Nie tylko ludzie niewidomi na jedno oko, ale również cierpiący na ślepotę przestrzenną ${ }^{11}$ przy odbieraniu przestrzeni nie mogą korzystać ze stereoskopii i przykładowo oglądanie trójwymiarowych filmów nie stanowi dla nich żadnej rozrywki. Mimo to wiele osób cierpiących na tę dolegliwość może widzieć w trzech wymiarach ${ }^{12}$, gdyż niektóre sygnały przestrzenne interpretowane przez mózg są odbierane przez jedno oko, niezależnie od drugiego.

A więc istnieją na pewno inne sposoby, jakimi posługuje się mózg przy określaniu głębi. Takimi sposobami może być np.:

- podświadoma ocena napięcia mięśni jednego oka, która daje nam możliwość oceny odległości od przedmiotu ${ }^{13}$, 
- jeżeli jeden obiekt zasłania częściowo drugi, to w sposób naturalny wiemy, który z nich znajduje się bliżej nas,

- wielkość obiektu też jest ważną wskazówką, ponieważ z reguły to, co większe, odbieramy jako bliższe,

- zasady perspektywy, na które człowiek jest szczególnie wrażliwy.

Ale czy rodzimy się z umiejętnością widzenia głębi przestrzeni?

Trudno na to pytanie udzielić jednoznacznej odpowiedzi. W czasie stuleci, w trakcie których filozofów i naukowców fascynowało to pytanie, powstały aż trzy szkoły starające się znaleźć odpowiedź na to pytanie.

Pierwsza z nich uważa, że chociaż widzimy przykładowo zbiegające się szyny kolejowe na horyzoncie, wiemy z doświadczenia, iż w rzeczywistości są do siebie równoległe. Dlatego umysł interpretuje otrzymane sygnały zgodnie z prawdą. Uświadamia sobie, że to, co mniejsze, jest w rzeczywistości bardziej odległe od naszych oczu.

Druga szkoła, wyjaśniająca sposób widzenia przez nas głębi, wykorzystuje termin Gestalt, który po niemiecku znaczy wzór lub forma. Uważa ona, że gdy patrzymy na jakąś scenę, nasz umysł intuicyjnie wychwytuje pełne jej znaczenie. Dlatego bezcelowe jest analizowanie, jak poszczególne fragmenty układają się w umyśle w całość. Przedstawiciele tej szkoły stwierdzają, że układają się zgodnie z przyjętym przez mózg wzorem.

Trzecia szkoła przyjmuje, że umysł odbiera wiele różnych wskazówek, świadczących o odległości innych niż np. zbliżanie się szyn do siebie. Jedną z najważniejszych jest ta, że zarys i faktura wszelkich obiektów stają się coraz mniej wyraźne, im dalej się znajdują. Oznacza to, że kojarzymy wyrazistość kształtów z bliskością, a ich mglistość z oddaleniem.

Według mnie w mózgu zachodzą procesy, które charakteryzują założenia tych trzech szkół ${ }^{15}$. Przykładowo F.H. Adler w swojej książce Fizjologia oka pisze, że psycholodzy twierdzą, że chociaż wszystkie informacje z obszaru percepcji są odbierane, to tylko ich niewielka liczba zostaje przetworzona.

Proces przetwarzania danych, napływających do danego człowieka, odbywa się w stałym tempie biologicznym, charakterystycznym dla danej osoby, ponieważ „dla każdego istnieje stały czas reakcji, stały czas adaptacji do nowych warunków...", a nasz mózg wybiera te informacje, które w danym momencie uważa za najważniejsze, najbardziej zbliżone do prawdy. Dlatego też możemy świadomie go oszukać, odpowiednio oddziałując na czynniki dwóch pierwszych wymiarów czynnikami wymiaru trzeciego.

W tym właśnie miejscu główną rolę w kształtowaniu postrzegania dzieła architektonicznego ${ }^{17}$ ma architekt. On to właśnie, przy odpowiednim użyciu czynników z wymiaru trzeciego, może wpływać na taki lub inny odbiór danego obiektu. Wrażenie, jakie będzie on wywierał na obserwatorze, wcale nie musi być zgodne z prawdą - odbierany rzut obiektu wcale nie musi być jego rzutem rzeczywistym, elewacja elewacją, powierzchnia powierzchnią, a kubatura kubaturą. Rzeczywisty kształt realizowanego obiektu nie musi mieć w efekcie końcowym dużo wspólnego z jego kształtem odbieranym przez obserwatora, a na ile 
rzeczywistość odbiega od uzyskanej iluzji, jest uwarunkowane kunsztem architekta oraz jego znajomością geometrii ${ }^{18} \mathrm{w}$ najszerszym tego słowa znaczeniu.

Stosując świadomie w trakcie projektowania zasady perspektywy, barwę, światłocień, zmienne faktury, odbicia lustrzane, kontrast czy też różne złudzenia optyczne, architekt może obiekty:

- zmniejszać i powiększać,

- poszerzać i zwężać,

- robić je niemal niewidocznymi w swoim otoczeniu lub też powodować, że będą przyciągały wzrok obserwatora,

- może do obiektów dodawać nieistniejące fragmenty architektury, takie jak: kopuły, sklepienia, wnęki, kaplice, korytarze, kolumny, okna itd.,

- może również ukryć część obiektu,

- lub też spowoduje, że z różnych obiektów stworzy nieistniejący w rzeczywistości obiekt, a wszystko w zależności od potrzeby, która może być podyktowana różnymi uwarunkowaniami ${ }^{19}$.

Przykładem takiego uwarunkowania mogą być przepisy policyjno-budowlane ${ }^{20}$, obowiązujące na terenach polskich w XIX wieku, które przyczyniły się do masowego wprowadzania dachów mansardowych na domach czynszowych w zwartej zabudowie miast polskich. Dalszym przekształceniem tego rodzaju dachu był cały system dachów niesymetrycznych, których widok od strony ulicy przypomina dach mansardowy. Stosowane były właściwie wyłącznie na budynkach w zabudowie zwartej w celu lepszego wykorzystania powierzchni poddasza oraz do upodobnienia od strony ulicy do dachu mansardowego, krytego u nas dachówką ${ }^{21}$, podczas gdy od strony podwórza występowała płaska połać kryta blachą lub tanią papą.

Na poniższych fotografiach przedstawiono obiekty powstałe w XIX wieku, a utrwalone na kliszach pochodzących z przełomu XIX i XX wieku.

Dobry architekt musi sobie również zdawać sprawę, że na odbiór jego dzieła mają też wpływ inne czynniki, nie tylko te, które oddziałują na zmysł wzroku. Duże znaczenie na odbiór dzieła architektonicznego mają również czynniki oddziałujące na inne zmysły: węch, słuch czy dotyk.

Czyż przykładowo kościół, katedra nie kojarzą się nam z półmrokiem, delikatnym szmerem modlitw wypełniających ciszę wnętrza, zapachem palących się świec i delikatną wonią unoszących się kadzideł oraz cichnącym dźwiękiem organów? Te wszystkie elementy połączone $z$ architekturą tworzą niezapomniane wrażenie, kształtują specyficzny odbiór dzieła architektonicznego - jedyny i niepowtarzalny.

Jeżeli architekt zapomni o pozostałych czynnikach, które będą towarzyszyć jego dziełu, gdy stworzy obiekt w oderwaniu od otoczenia i nie weźmie pod uwagę psychiki ludzkiej, tradycji oraz przyzwyczajeń ludzkich, to może się okazać, że najgenialniejszy projekt, który stworzy na papierze lub nawet w modelu, nie spełni oczekiwań jego i odbiorców. Może być zupełnie inaczej postrzegany, niż to, co było w jego założeniu, a w efekcie końcowym nie przyjęty przez odbiorcę tak jak się tego autor spodziewał. Nie może się wówczas dziwić, że jego „odrzucone” dzieło zostanie przez odbiorców zmienione, przeprojektowane lub przebudowane. 


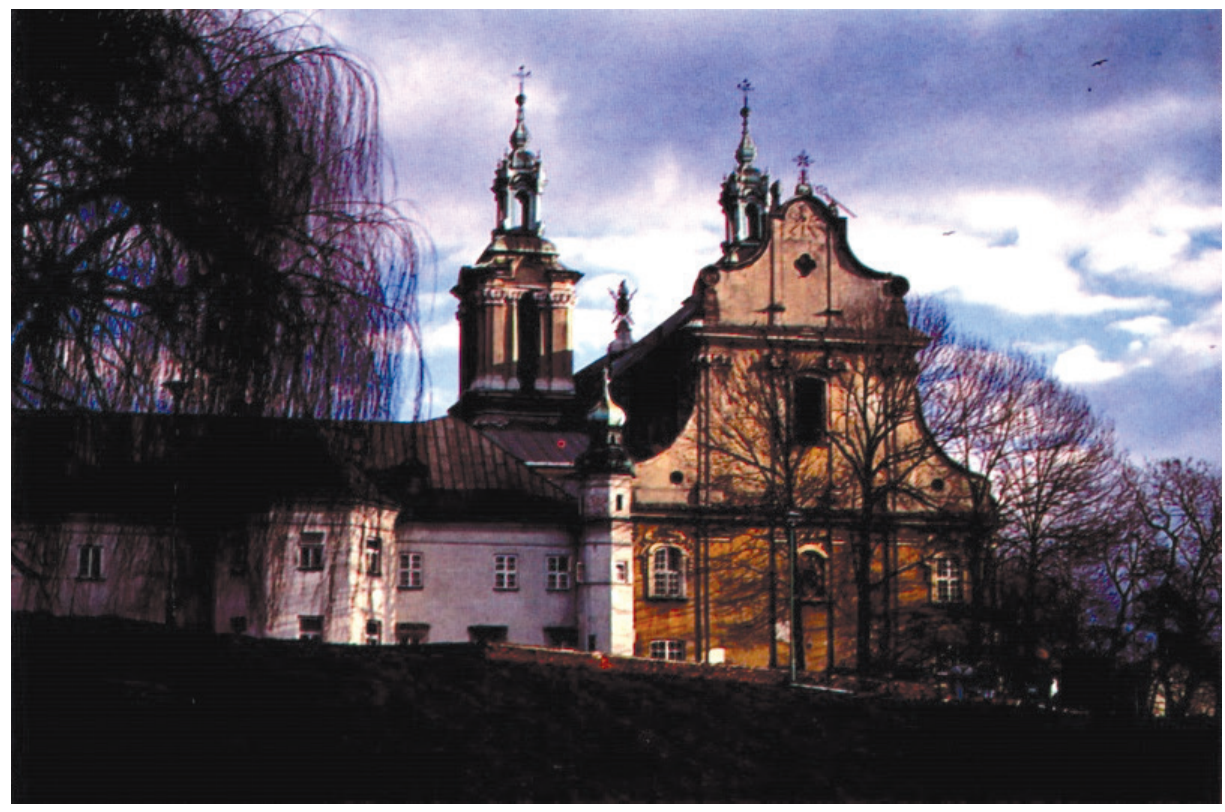

II. 1. Dachy klasztoru i kościoła OO. Paulinów na Skałce w Krakowie w promieniach popołudniowego, jesiennego słońca, na tle zasłanego obłokami nieba

III. 1. The roofs of the Pauline Church on the Rock in Kraków, in the afternoon, autumn sun, on the background of cloudy sky
1. ostrość wzroku, ...
2. pole widzenia, ...
3. motoryka
4. funkcje mózgowe
5. recepcja światła i barw, ...
6. cechy fizyczne
7. cechy psychiczne
8. percepcja
9. integracja sensoryczna
10. poznanie
11. barwa, ...
12. kontrast
13. czas
14. przestrzeń
15. oświetlenie, ...

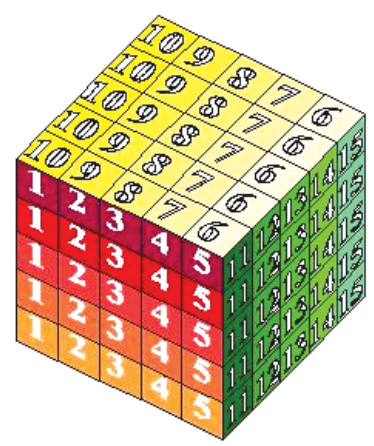

II. 2. Model przestrzenny przedstawiający czynniki mające wpływ na postrzeganie otaczającej nas przestrzeni, opracowany przez Anne L. Corn. Rysunek modelu wykonany został na podstawie ilustracji zamieszczonej w czasopiśmie „Wiedza i Życie” 2/92

III. 2. A spatial model showing the factors that influence the perception of the surrounding space, developed by Anne L. Corn. Drawing of the model was made on the basis of a figure appearing in the journal "Wiedza i Życie" 2/92 

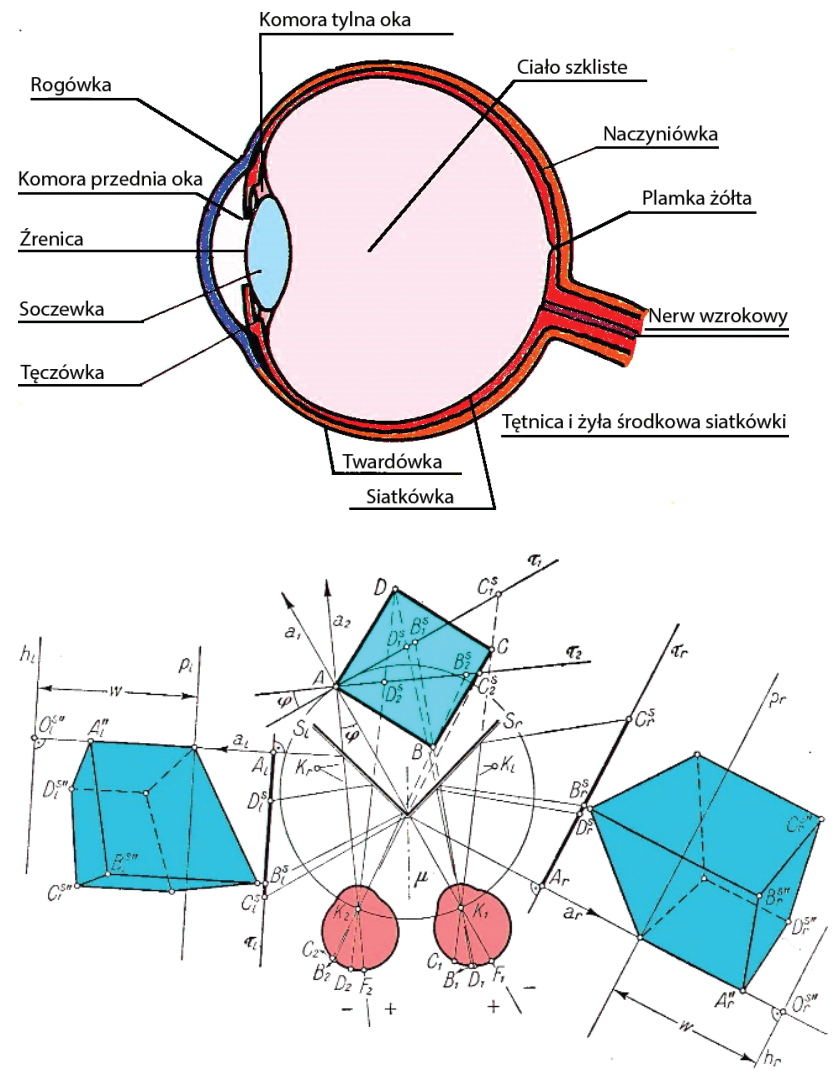

II. 3. Budowa oka ludzkiego

III. 3. Anatomy of the human eye

II. 4. Zasada widzenia binokularnego. Rysunek zamieszczony w II tomie Perspektywy malarskiej prof. K. Bartla

III. 4. The principle of the binocular vision. Drawing contained in the II volume of Perspective in painting by professor K. Bartel

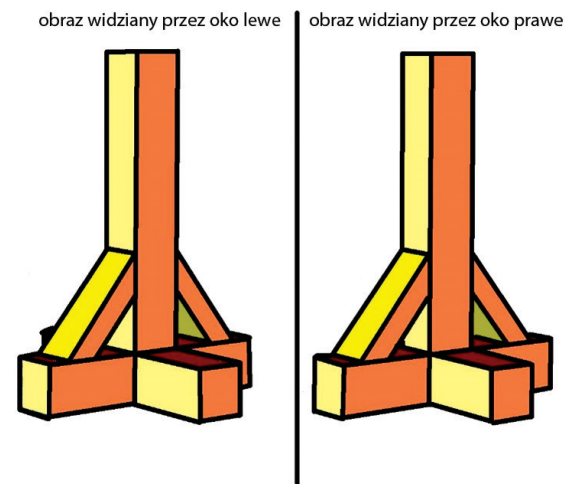

II. 5. Lewe i prawe oko człowieka rejestruje obraz obiektu trochę inaczej. Dopiero złożenie obu tych płaskich obrazów daje nam obraz przestrzenny oraz wrażenie głębi

III. 5. The left and right eye captures the image of the object a little differently. Only the merger of both of these flat pictures gives us the spatial image and impression of depth 


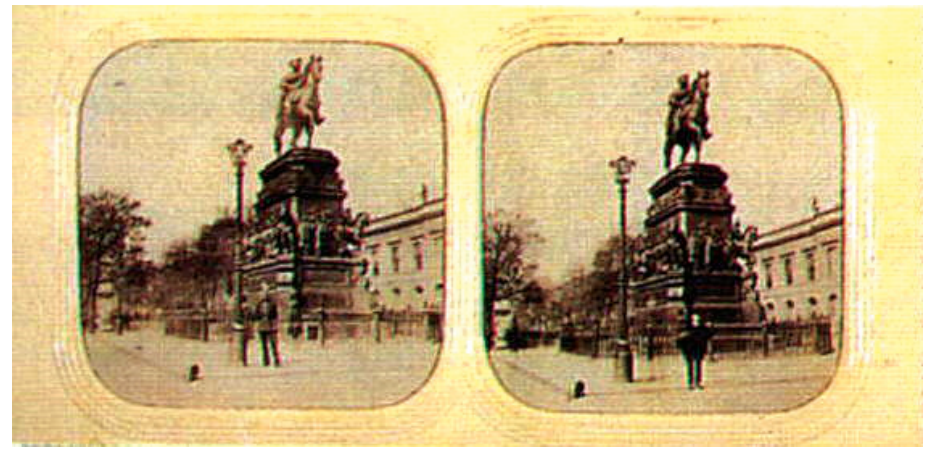

II. 6. Plac Matejki z pomnikiem grunwaldzkim w Krakowie uwieczniony na parze zdjęć przygotowanych do stereoskopu Davida Brewstera. Zdjęcia te wykonano oddzielnie ${ }^{9}$, w niewielkim oddaleniu od siebie, za pomocą zwyczajnego aparatu fotograficznego, starając się jedynie oddać widok z każdego oka

III. 6. Matejko Square with the Battle of Grunwald monument in Kraków captured on a pair of photographs prepared for the David Brewster's stereoscope. These photos were made separately ${ }^{9}$ in a small distance from each other, using ordinary camera, trying to only show the view from each eye
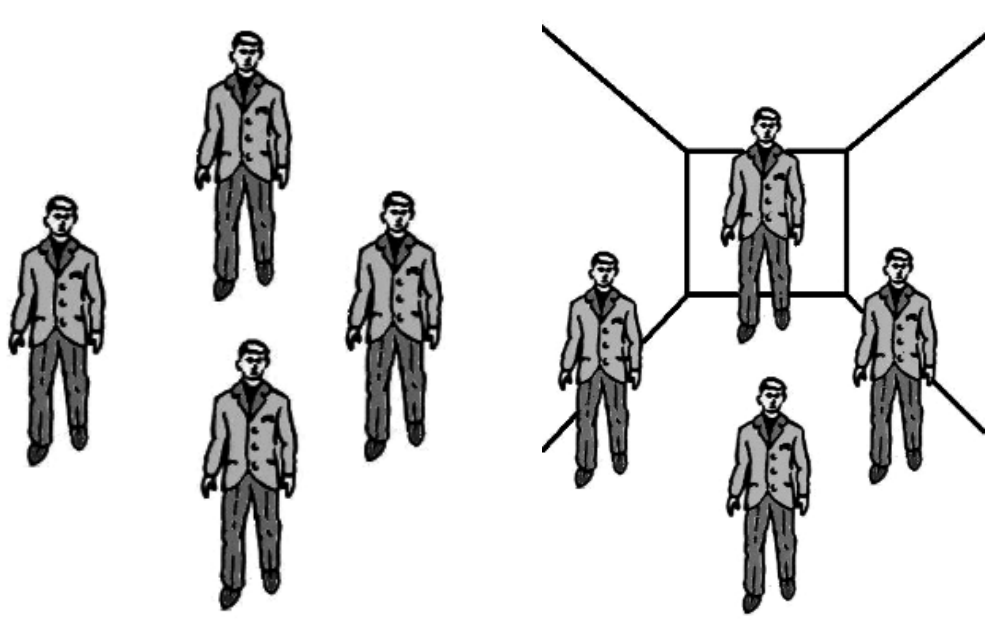

II. 7. Powyższy rysunek pokazuje nam, jak głęboko w naszej świadomości zakorzeniona jest umiejętność odczytywania perspektywy. Dorysowanie paru linii, które w naszej podświadomości obrazują jej zasady, spowodowało, że postać stojąca najbliżej dolnej krawędzi wydaje się „karłem”

w porównaniu z postacią umieszczoną najwyżej, która wydaje nam się „olbrzymem” - mimo iż wszystkie postaci są w rzeczywistości identycznej wielkości

III. 7. The image above shows how deeply is the ability to view perspective rooted into our consciousness. Adding a few lines that in our subconscious reflect its principles, caused the person standing closest to the bottom line seem to be a "dwarf" in comparison with the person placed the highest, who seems to us to be "giant" - despite the fact that all the persons are in fact the same size 


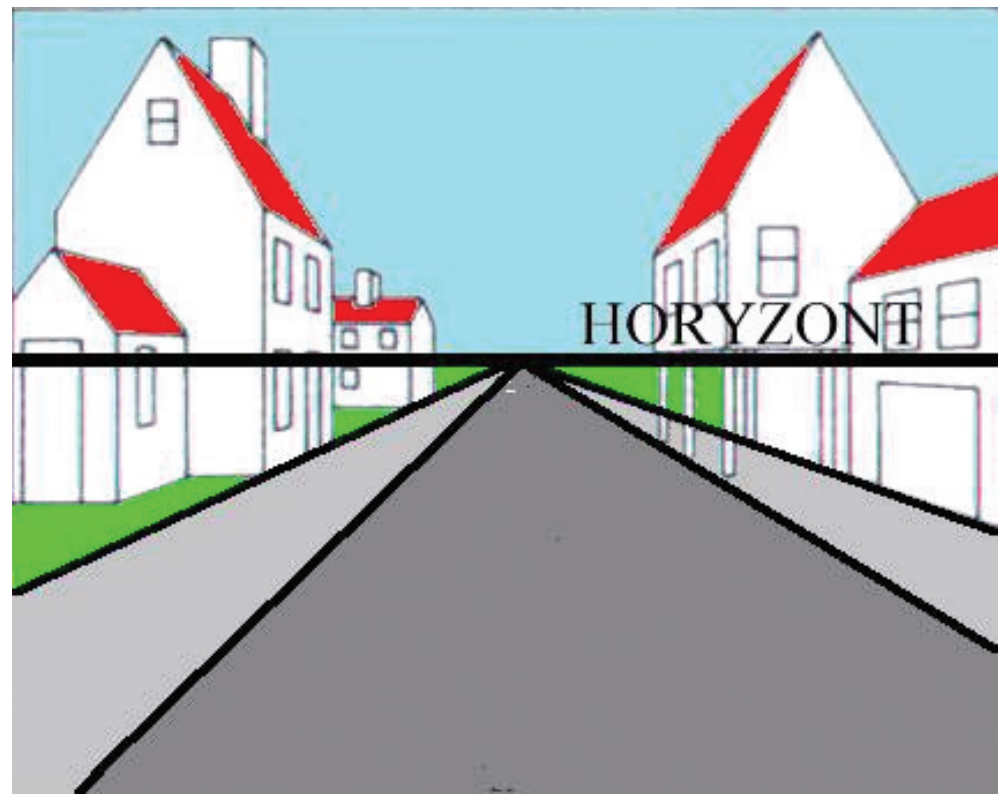

II. 8. Równoległe linie drogi zbiegają się w jednym punkcie na horyzoncie

III. 8. Parallel lines of the road meet at one point on the horizon
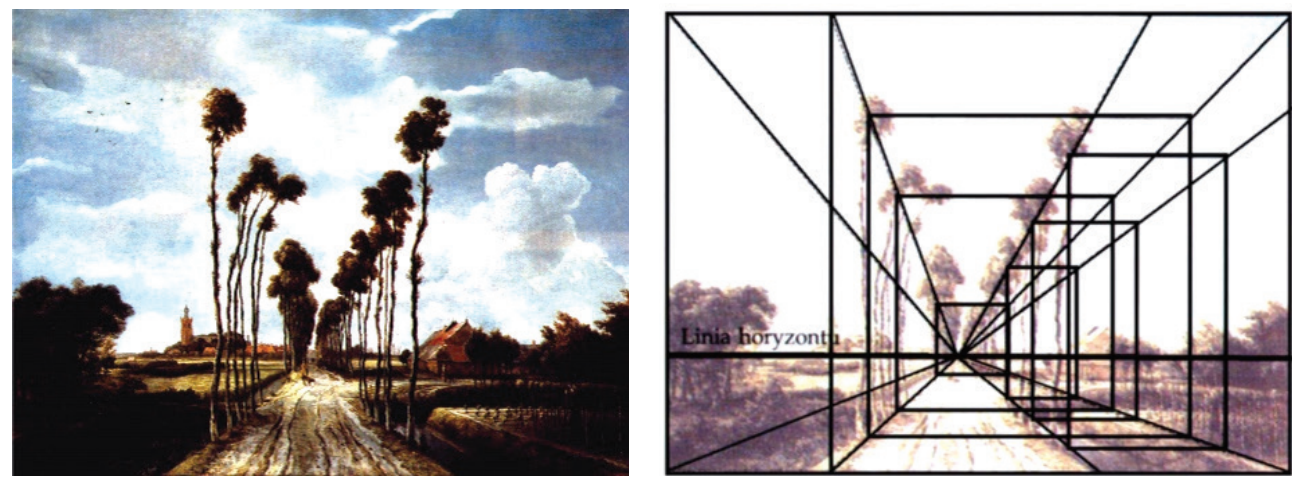

II. 9. Słynna „Aleja w Middelharnis” Meinderta Holberga jest bardzo dobrym przykładem na ukazanie głębi przez zastosowanie typowo geometrycznego schematu perspektywy centralnej. Dzięki temu pejzaż ten przyciąga wzrok obserwatora w głąb alei. Ten sam efekt można uzyskać nie tylko na obrazie

III. 9. The famous "The Avenue at Middelharnis" by Meindert Holberg is a very good example to show the depth by applying a typically geometric pattern of central perspective. Thanks to that, this landscape attracts the viewer's eyes into the avenue. The same effect can be achieved not only on the image 

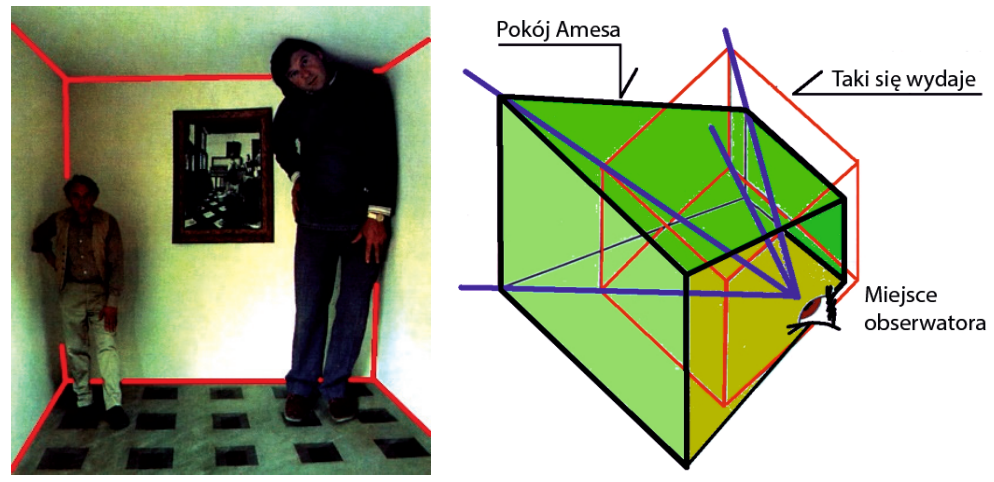

II. 10. Nie zawsze jednak to, co widzimy, a właściwie to, co wydaje się nam, że widzimy, jest zgodne z rzeczywistością. Jak zwodnicza potrafi być geometria trójwymiarowych obiektów najlepiej chyba ilustruje „Pokój Amesa” ${ }^{14}$. Patrząc na niego (po stronie lewej), wydaje się nam, że widzimy prostopadłościenny pokój, w którym przebywają jednocześnie karzeł i olbrzym. Rzeczywistość jest jednak całkowicie inna. Pomieszczenie to jest sześcioboczną, nieregularną konstrukcją, w której tylna

ściana, podłoga i sufit są pochyłe, a znajdujący się wewnątrz niej ludzie są podobnego wzrostu

III. 10. Not always, however, what we see, and actually, what we think we see, is consistent with reality. The misleading nature of geometry of three-dimensional objects is probably best illustrated by the "Ames room $^{\prime 14}$. Looking at it (on the left), it seems to us that we see a rectangular room, with a dwarf and a giant

in it. The reality, however, is completely different. The room is a hexagonal, irregular structure, in which the rear wall, floor and ceiling are inclined, and the people inside are of similar height

II. 11. Nokturn w błękicie i złocie - James Abbott McNeill Whistler

III. 11. Nocturne: Blue and Gold - James Abbott McNeill Whistler

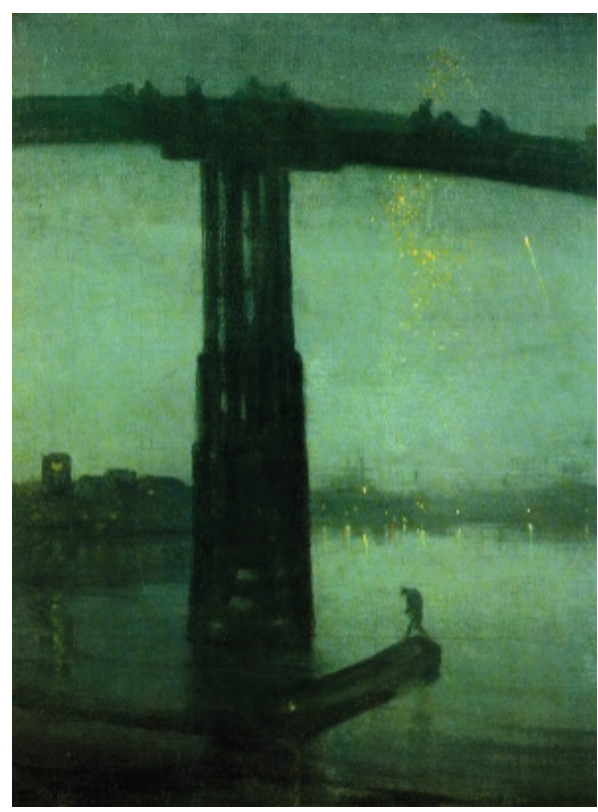




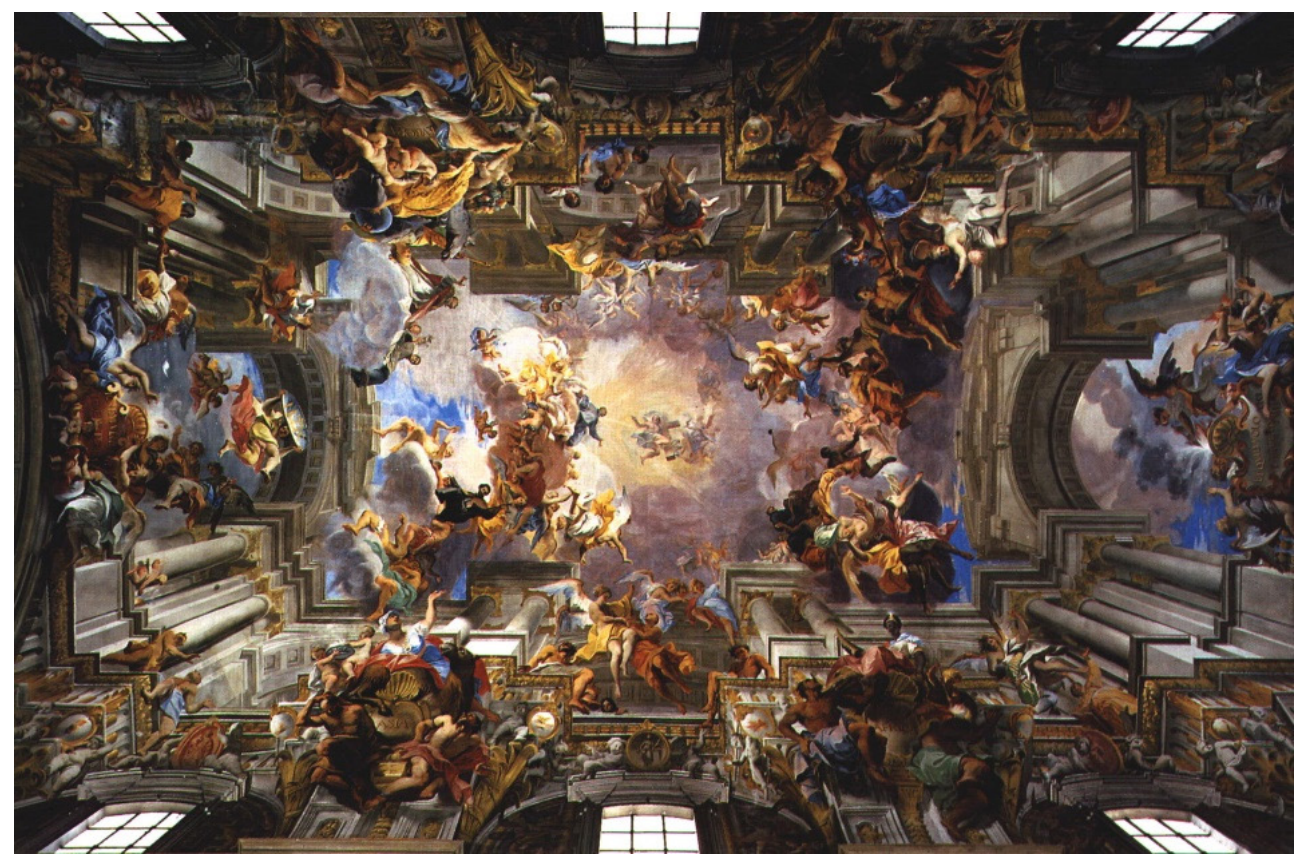

II. 12. Świat iluzji - znika granica pomiędzy architekturą rzeczywistą a namalowaną sklepienia nawy głównej kościoła S. Ignazio w Rzymie, dzieła Andrei Pozza ${ }^{16}$

III. 12. World of illusion - the division into actual and painted architecture disappears on the nave's barrel vault of the Church of S. Ignazio in Rome, painted by Andrea Pozza ${ }^{16}$

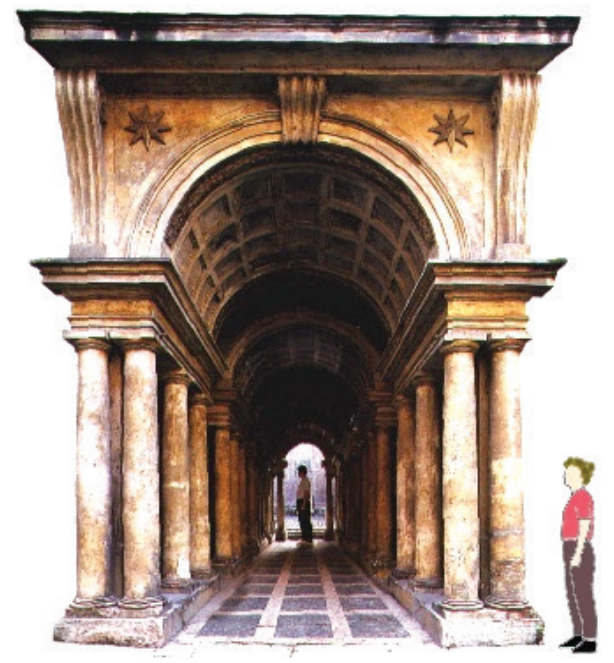

II. 13. Arkadowe przejście prowadzące

z wewnętrznego ogrodu w Palazzo Spada w Rzymie do małego dziedzińca ma w rzeczywistości 8,85 m. Efekt nierzeczywistej głębi Francesco Borromini uzyskał przez naśladowanie efektów perspektywicznych kolumny na początku są grubsze, a na końcu cieńsze, gzymsy opadają, natomiast podłoga wznosi się i posiada wzór nie kwadratowy, jak by się nam mogło wydawać, ale złożony z trapezoidalnych kształtów III. 13. Arcaded passage from the internal garden in Palazzo Spada in Rome to a small courtyard that has in fact $8.85 \mathrm{~m}$. The effect of unreal depth was obtained by Francesco Borromini by mimicking the effects of perspective - column in front are thicker and those in the end are thinner, cornices fall, while the floor rises and has a pattern, which is not a square, as it appear, but is made of trapezoidal shapes 

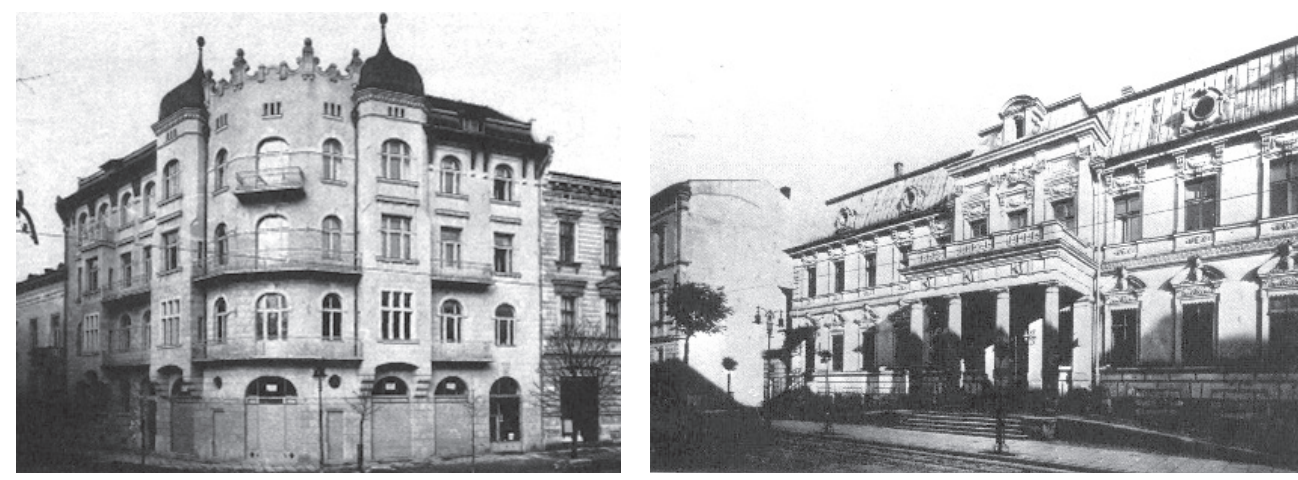

II. 14. Dom Jana Kantego Federowicza, zaprojektowany przez Teodora Hoffmana, mieszczący się w Krakowie przy ul. Świerczewskiego ${ }^{22}$

III. 14 House of Jan Kanty Federowicz, designed by Theodore Hoffman, located in Kraków, ul. Świerczewskiego 22

II. 15. Pałac Potulickich, zaprojektowany przez Leonarda Marconiego i Filipa Pokutyńskiego, mieszczący się w Krakowie przy ul. Józefa Piłsudskiego $4^{23}$

III. 15. Potuliccy Palace, designed by Leonard Marconi and Filip Pokutyński, located in Krakow, ul. Józefa Piłsudskiego $4^{23}$
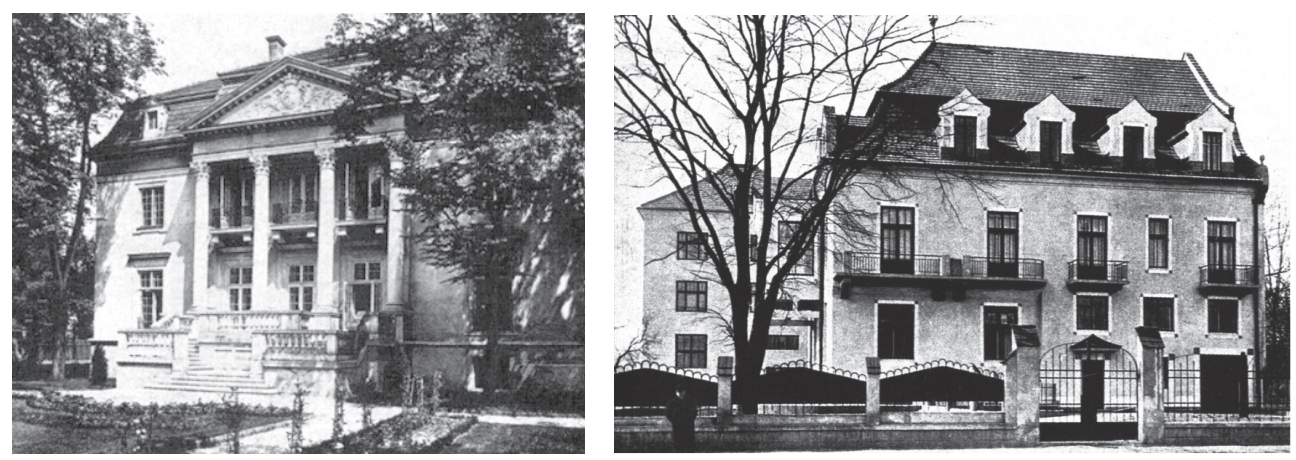

II. 16. Pałac Mańkowskich, zaprojektowany przez Władysława Kaczmarskiego i Józefa Sowińskiego, mieszczący się w Krakowie przy ul. Topolowej $5^{24}$

III. 16. Mańkowscy Palace, designed by Władysław Kaczmarski and Józef Sowiński, located in Kraków, ul. Topolowa $5^{24}$

II. 17. Gmach Lecznicy Związkowej, zaprojektowany przez Tadeusza Stryjeńskiego i Franciszka Mączyńskiego, mieszczący się w Krakowie przy ul. Garncarskiej $11^{25}$

III. 17. The building of the Federal Clinics, designed by Tadeusz Stryjeński and Franciszek Mączyński, in Kraków, ul. Garncarska $11^{25}$ 


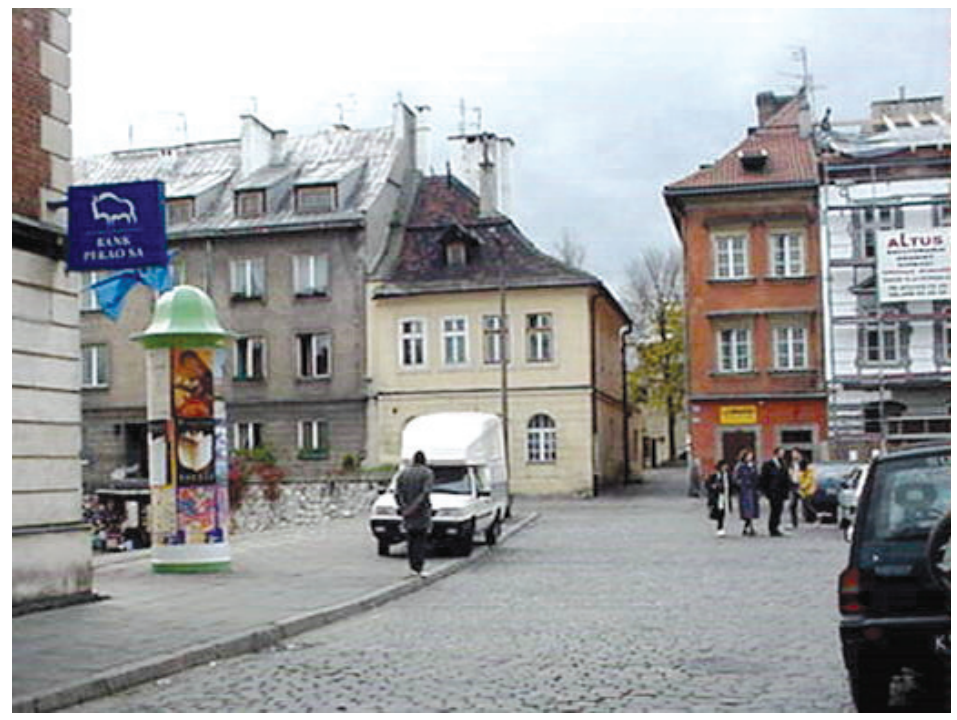

II. 18. Stare i na nowo kształtowane dachy krakowskiego Kazimierza - domy przy ulicy Szerokiej w Krakowie

III. 18. Old and newly shaped roofs of Kazimierz - house at ul. Szeroka in Kraków 


\section{PRZYPISY}

1 Właściwa ludziom i zwierzętom zdolność wykonywania ruchów, kierowania czynnościami.

2 Przyjmowanie, przyswajanie.

3 Uświadomienie, całościowe odbieranie bodźców zewnętrznych i ich strukturalizacja, uzależniona od zainteresowań, czynników emocjonalnych i społecznych działających na jednostkę oraz od osobowości jednostki; spostrzeganie, odbiór.

4 Sensoryczny, czyli dotyczący poznawania za pomocą zmysłów; czuciowy, wrażeniowy.

5 Odbioru.

6 Zjawisko to nazywa się ślepotą korową. Oczy ludzi nią dotkniętych reagują normalnie na światło, chociaż w ich mózgach nie powstają żadne obrazy.

7 Znaków.

8 Obrazom, odczuciom, dźwiękom.

9 Ciekawą rzeczą jest fakt zanotowania upływu czasu pomiędzy wykonaniem obu tych zdjęć. Upływ czasu zaznaczył się tym, że na miejscu policjanta widocznego na lewym zdjęciu pojawia się chłopiec (na zdjęciu prawym).

10 Przykładowo świetnie prowadzą samochód.

${ }^{11}$ Polegającą na niemożności ustawieniu oczu tak, by wychwycić sygnały przestrzenne, które normalnie odbieramy przy widzeniu dwuocznym.

${ }^{12}$ A nawet pracować w zawodach, w których konieczna jest umiejętność wyobraźni przestrzennej.

${ }^{13}$ Ale ocena ta jest na pewno mniej dokładna, niż gdy patrzymy na dany obiekt obu oczami.

14 Zdjęcie „Pokoju Amesa” wykonał John Hedgecoe.

${ }^{15}$ Czyli wszystkie po części mają rację.

16 „Alegoria misji jezuickich” to fresk namalowany w latach 1691-1694.

17 W tym również dachu.

18 Zwłaszcza perspektywy, złudzeń optycznych, odbić lustrzanych, gry światłocieni.

19 Podyktowana przykładowo przez ukształtowanie terenu, lokalizację, prawa budowlane, zezwolenia, wymagania inwestora, modę, materiały budowlane czy też w końcu możliwości finansowe zleceniodawcy.

20 Przepisy te z jednej strony ograniczały wyraźnie wysokość domów wielopiętrowych, a z drugiej zawierały przepisy, sprzyjające powstawaniu zamaskowanych pięter ponad najwyższą dozwoloną wysokością domu. Przepis ten miał następujące brzmienie:

Nachylenie dachu przy całkowitym wyzyskaniu dozwolonej wysokości nie powinno przekraczać $60^{\circ}$, suma zaś występów mansardowych połowy długości frontu budynku.

Warto zaznaczyć, że wspomniane tu występy mansardowe to nic innego jak okienka pomieszczeń mieszkalnych poddasza mansardowego.

${ }^{21}$ We Francji pokryciem dominującym był łupek, u nas prawie nie występujący. 
22 Muzeum Narodowe w Krakowie, Pracownia Ikonografii Krakowa Muzeum Narodowego w Krakowie, nr inw. 5900.

${ }^{23}$ Muzeum Narodowe w Krakowie, Pracownia Ikonografii Krakowa Muzeum Narodowego w Krakowie, nr inw. 3919.

${ }^{24}$ Muzeum Narodowe w Krakowie, Pracownia Ikonografii Krakowa Muzeum Narodowego w Krakowie, nr inw. 4091.

25 „Architekt”, t. 11, 1900, tabl. XI. 3.6.

\section{BIBLIOGRAFIA}

„Architekt”, t. 11, 1900.

Arnheim R., Sztuka i percepcja wzrokowa, WAiF, Warszawa 1978.

Broniewski T., Historia architektury dla wszystkich, Ossolineum, Wrocław 1964.

Geometria i grafika w przestrzeni architektonicznej, pod red. K. Romaniak, Wydawnictwo Politechniki Krakowskiej, Kraków 2016.

Kantarek A.A., O orientacji w przestrzeni miasta, Wydawnictwo Politechniki Krakowskiej, Kraków 2013.

Purchla J., Fabiański M., Architektura Krakowa - Przewodnik, Wydawnictwo Literackie, Kraków 2013.

Zdziarski A., Jonak M., Anamorphic images on the historical background along with their classification and some selected examples/Obrazy anamorficzne na tle historycznym wraz z klasyfikacjq i wybranymi przykładami, Technical Transactions, 1/ 2017, s. 25-40. 